\title{
Archivo y desmemoria en Agua viva de Clarice Lispector
}

\author{
Mariela Herrero \\ Facultad de Humanidades y Artes \\ Universidad Nacional de Rosario \\ herreromariela@gmail.com
}

\section{Resumen}

En el presente artículo se pretende analizar la obra Agua viva (1973) de la brasilera Clarice Lispector a partir del examen de algunas de las estrategias narrativas y reformulaciones artísticas que formaron parte de un proceso de radicalización de la escritura de Lispector, llevado a cabo y profundizado durante los años 70 . El objetivo del estudio apunta a vincular el contexto político y la censura que tuvo lugar en Brasil desde el año 1964 con una toma de posición artística e intelectual que, frente a esa situación, tuvo que ser reconsiderada.

Ante la opción de construir obras que mostraran una realidad redentora, que funcionaran como «salidas» a las condiciones históricas, Lispector eligió escribir exponiendo el proceso de construcción de la obra. Así, al exhibir la experiencia de una escritura contaminada de una situación histórica conflictiva, se proponía a la obra como el lugar de una experiencia de crisis.
Palabras clave: archivo, censura, literatura brasilera, Clarice Lispector, diario íntimo. 
A partir de esto y, coincidiendo con buena parte de los estudios críticos que dedicaron sus investigaciones a Agua viva, consideramos que éste se presenta como un texto de difícil clasificación genérica y, desde allí, proponemos un intento de analizar este texto como cercano a las formas del diario íntimo aunque, sin embargo, logra mantener la estructura y las características de una ficción.

\section{Abstract}

The present article is intended to analyzes the play «Living Water» (1973) of the brasilian Clarice Lispector from the review of some narrative strategies and artistic reformulations that were part of a process of radicalization of Lispector's writing, carried out and deepened during the 7os. The objective of the study aims to link the political context and the censorship that took place in Brazil since 1964 with a shot of an artistic and intellectual position, wich, faced with that situation, had to be reconsidered.

In view of the option of build works that showed a redeeming reality, which function as «exits» to historical conditions, Lispector chose to write exposing the construction process of the work. Thus, by displaying the experience with a writing contaminated of a conflicting historical situation, it proposed to the play as the site of a crisis experience.

From this and, coinciding in good part with the critical studies wich dedicated their investigations to «Living Water». We consider that this one presents itself as a text of difficult generic classification and, from there, we propose an attempt to analyze this text closer to the intimate diary forms though, however, manages to preserve the structure and characteristics of a fiction.

\section{Key words:}

file-censorship, Brazilian literature, Clarice Lispector, intimate diary. 